\title{
LIQUEFIED NATURAL GAS TENDER CRASHWORTHINESS RESEARCH
}

\author{
David Tyrell \\ Volpe National Transportation Systems Center \\ United States Department of Transportation \\ Cambridge, Massachusetts, USA
}

\section{ABSTRACT}

Research is being conducted to develop technical information needed to formulate effective natural gas fuel tender crashworthiness standards. This research is being performed for the Federal Railroad Administration's (FRA's) Office of Research, Development, and Technology, and intended to facilitate industry efforts to use natural gas as a locomotive fuel. Strategies to assure crashworthiness during moderate accidents, such as train-to-train collisions at speeds up to $40 \mathrm{mph}$, are being evaluated.

This research applies the approach FRA has used to develop technical information on locomotive, hazmat tank car, and diesel fuel tank crashworthiness. There are four primary tasks:

1.Definition of collision scenarios

2.Evaluation of traditional designs

3.Evaluation of alternative designs

4.Recommendation of effective crashworthiness strategies

The tender scenarios have been drafted from reviews of freight train accidents and of scenarios developed for locomotives, hazmat tank cars, and fuel tanks. From these reviews, five scenarios were selected. These scenarios are intended to bound the range of collisions that a tender may experience, are being used to evaluate the crashworthiness of traditional tender designs, and will be used to evaluate alternative design tenders. The five candidate scenarios are:

1.Train-to-train collision

2. Grade-crossing accident

3. Tender derailment and rollover

4.Impact into tender tank shell during derailment

5.Impact into tender tank head during derailment

As part of previous research on locomotives and passenger equipment, a range of crashworthiness analysis techniques were developed. These include simplified techniques, which can be performed rapidly and provide essential results, and detailed computer simulations which provide a wealth of information. The crashworthiness performance of a hypothetical tender design has been evaluated using simplified techniques. Simplified techniques include quasi-static crush analysis of structural elements and lumped-parameter analysis of train dynamics. The results suggest that efforts to enhance crashworthiness should principally be directed toward the trainto-train scenario. Work is ongoing to develop strategies for improving tender crashworthiness.

This research is being conducted cooperatively with the Association of American Railroads (AAR). The research results are being shared with the AAR's Natural Gas Fuel Tender Technical Advisory Group (NGFT TAG). The NGFT TAG is developing industry standards, including crashworthiness requirements, for revenue-service natural gas fuel tenders. There is a companion paper which describes crashworthiness research sponsored by AAR, including detailed computer simulations of tender crashworthiness. This paper describes development of scenarios and simplified analyses of tender crashworthiness.

\section{INTRODUCTION}

The Volpe National Transportation Systems Center (Volpe Center) has been supporting FRA's Equipment Safety Research Program by conducting research on liquefied natural gas fuel tender crashworthiness. The goal of this research is to develop technical information needed to formulate effective tender crashworthiness standards. Results of this research are being shared with AAR NGFT TAG, which is developing standards, including crashworthiness requirements, for revenue-service natural gas fuel tenders.

\section{BACKGROUND}

Information from previous rail equipment crashworthiness research has been used to develop FRA regulations [1, 2, 3],

This material is declared a work of the U.S. Government and is not subject to copyright protection in the United States. Approved for public release; distribution is unlimited. 
AAR Standards [4], APTA Standards [5, 6], and railroad specifications [7]. In particular, locomotives compliant with current requirements for locomotive crashworthiness, including AAR S-580 [4] and 49 CFR 229 [3], appear to be accepted as having greater crashworthiness than locomotives designed to previous requirements. Train crews have survived accidents in newer-design locomotives, such as Valparaiso, Indiana, [8], that may have challenged older-design locomotives.

Modern crashworthiness requirements extend traditional crashworthiness requirements. Traditional requirements are oriented towards strong structures, and typically require that rail structures be designed to support large loads. Modern requirements add managing the load path and controlled deformation to the traditional orientation of strong structures. Managing the load path inhibits override between colliding and coupled cars. Controlled deformation inhibits catastrophic collapse of car structures. Modern crashworthiness requirements include collision scenarios, in which the primary structure must remain intact and the loads must be transferred effectively between cars.

Computer simulations are used to show that equipment designs perform as intended in the required collision scenarios. Such models can provide great detail on how collisions unfold; they are, however, susceptible to 'garbage in/garbage out.' Modeling uncertainties for finite element analysis are associated with inappropriate meshing, incorrect element type, and excessive material failure approximations. In addition, input errors can be made on the structure gross geometry, structure details, and the material properties. Any such errors can result in simulations that superficially appear to be realistic, but on close inspection are found to be fictitious.

Confidence in computer simulation results can be increased when the computer model is validated with reality checks. Figure 1 qualitatively illustrates the available techniques, which include material, component, car, and train tests, as well as accident reconstruction.

Process validation shows that the modeling approach produces results that compare closely with test results or accident consequences for equipment of a different design. Accident reconstruction with computer simulations can be helpful in understanding the crashworthiness of existing designs and in developing underlying confidence in simulation modeling techniques. With process validation, it can be shown that particular modeling procedures can be used to produce credible results.

Model validation shows that the model itself produces results that compare closely with test results for the design being evaluated. Tests of materials, components, cars, and trains can all be used for model validation. Such tests may be non-destructive or destructive. There is a wide range in costs in performing such tests. Generally, tests for increasing modeling confidence result in increasing costs.

For rail passenger equipment crashworthiness, worldwide practice includes validating collision simulation models with destructive material and component tests and non-destructive carbody tests $[9,10]$. The non-destructive carbody tests, which are similar to the traditional 800 kip buff strength test, are used to validate the modeling of the carbody gross and fine geometry and the elastic material properties. The destructive material tests are used to validate the material plastic behavior under uniaxial strain, and help reduce uncertainty associated with regions of high strain. And the destructive tests are used to validate the modeling of components such as structural fuses, energy absorbers, and deformable anti-climbers. Such tests minimize the uncertainty of the modeling of structures that deform into complex geometries.

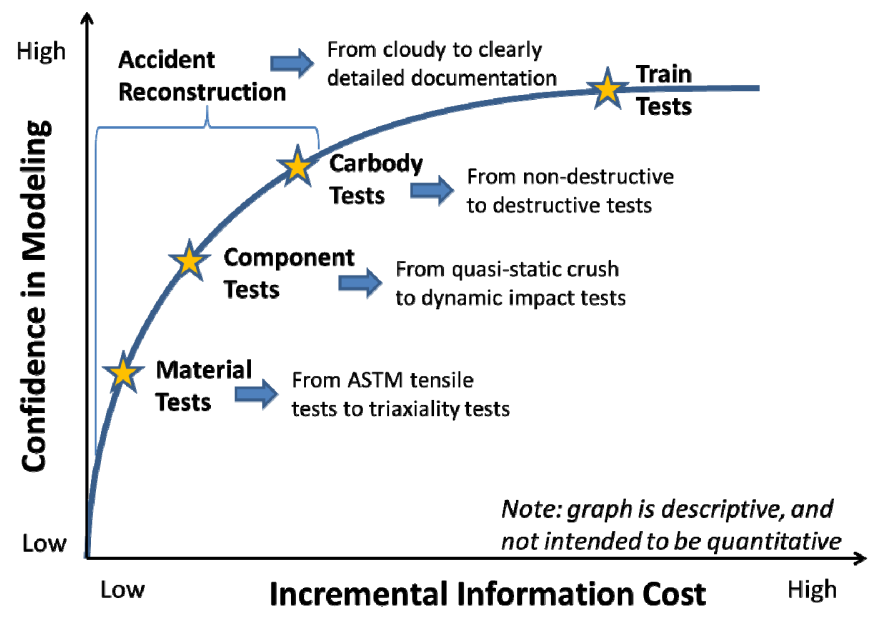

\section{Fig. 1. FLOW DIAGRAM DESCRIBING RESEARCH}

It is not possible to completely eliminate uncertainty, even with fullscale train-to-train impact tests. At a minimum, there will be differences among tenders of identical design due to variations from manufacturing. Such differences could potentially alter crashworthiness performance. However, the uncertainty of computer simulation models of rail equipment crashworthiness can be significantly reduced with reality checks. Finding the sweet spot in the tradeoff between confidence in modeling and incremental information cost involves many layers, and is likely to require judgment.

\section{APPROACH}

The focus for the fuel tender crashworthiness research is on moderate accidents, such as train-to-train collisions at speeds up to $40 \mathrm{mph}$. Crashworthiness strategies for fuel tenders are sought which result in fuel tender performance that is comparable to the performance of locomotives compliant with AAR S-580 crashworthiness standard [4] and AAR S5506 fuel tank standard [11].

The approach to the research is shown schematically in Figure 2. There are four steps to this research:

Step 1: Define accident scenarios

Step 2: Evaluate traditional designs

Step 3: Evaluate alternative designs

Step 4: Compare effectiveness

The scenarios sought are rare events, events that occur roughly between once a year and once every ten years on the North American general railroad system. The evaluations, for both the traditional and alternative designs, are estimates of the speed at which the limits of a criterion are reached, such as breach of the fuel tank. And the comparisons are expected to lead to recommendations for worthwhile crashworthiness features, such as underframe strength.

This material is declared a work of the U.S. Government and is not subject to copyright protection in the United States. Approved for public release; distribution is unlimited. 


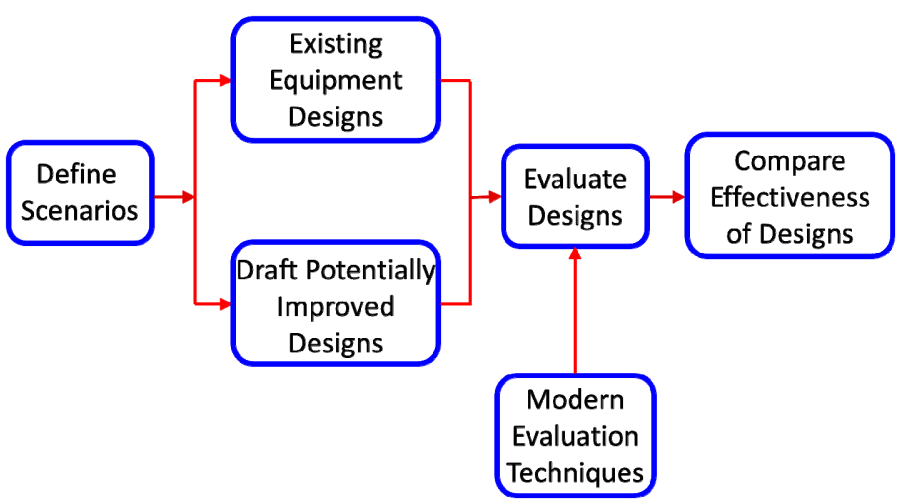

Fig. 2. FLOW DIAGRAM DESCRIBING RESEARCH APPROACH.

This paper describes the results of research that has been done. Research results include drafting of candidate scenarios and evaluations of hypothetical tender performance in these scenarios. The hypothetical tender is based on a DOT 113 tank car design. Research is ongoing to draft and evaluate alternative modern designs.

\section{OVERVIEW OF CANDIDATE SCENARIOS}

The scenarios include descriptions of the colliding equipment, description of the track conditions, definition of the pass/fail criteria, and definition of the minimum impact speed. The scenarios allow comparison of the crashworthiness performance of alternative designs. The scenarios have been drafted by reviewing scenarios from other areas of rail crashworthiness [12, 13,14, and 15] and by reviewing accident history. What was sought in these reviews were events that appeared likely to occur somewhere between once a year and once every ten years. Since these are statistically rare events, these scenarios have been selected with the application of judgment.

Table 1 lists the five candidate scenarios: a train-to-train collision, a grade crossing collision, rollover, head impact, and shell impact. These last three scenarios, rollover, head impact, and shell impact, are all associated with derailment.

Table 1. CANDIDATE SCENARIOS

\begin{tabular}{|l|l|l|l|}
\hline \multicolumn{2}{|c|}{ Scenario } & \multicolumn{1}{c|}{ Mode } & \multicolumn{1}{c|}{ Threat } \\
\hline 1 & $\begin{array}{l}\text { Train-to-train } \\
\text { collision }\end{array}$ & $\begin{array}{l}\text { High underframe } \\
\text { compressive load }\end{array}$ & $\begin{array}{l}\text { Underframe } \\
\text { crippling }\end{array}$ \\
\hline 2 & $\begin{array}{l}\text { Grade- } \\
\text { crossing } \\
\text { impact }\end{array}$ & $\begin{array}{l}\text { Impact into tender } \\
\text { side plumbing }\end{array}$ & $\begin{array}{l}\text { Valve and fitting } \\
\text { enclosure failure }\end{array}$ \\
\hline 3 & Rollover & $\begin{array}{l}\text { Impact into tender } \\
\text { roof plumbing }\end{array}$ & $\begin{array}{l}\text { Valve and fitting } \\
\text { enclosure failure }\end{array}$ \\
\hline 4 & Shell impact & $\begin{array}{l}\text { Focused impact } \\
\text { into fuel tank shell }\end{array}$ & Tank breach \\
\hline 5 & Head impact & $\begin{array}{l}\text { Focused impact } \\
\text { into fuel tank head }\end{array}$ & Tank breach \\
\hline
\end{tabular}

\section{SIMPLIFIED ANALYSES}

The performance of a hypothetical traditional tender has been evaluated in the five candidate scenarios. This paper describes the results of simplified analyses. 'Simplified analyses' in this case means manual calculations for two of the scenarios; and computer simulations with only one-dimensional motion and no more than six degrees of freedom for three of the scenarios.

One-dimensional train collision dynamics models were used to analyze the response of the hypothetical traditional tender in Scenarios 1, 4, and 5. Figure 3 illustrates the simplified analysis approach used. This approach is similar to the approach used in previous locomotive crashworthiness research $[16,17]$. The collisions are analyzed in two steps:

Step 1: Car Crush Behavior. Dynamic, non-linear, large displacement finite-element models of the structures loaded in the scenarios have been developed. These models approximate the loading conditions in the collision. The principal purpose of these models is to develop the force/crush behavior for different locomotive structure designs for use in developing the crush elements of the collision dynamics models.

Step 2: Train Collision Dynamics. One-dimensional lumped-parameter collision dynamics models have been used to estimate the distribution of damage. Impact elements have been used in these collision dynamics models, with the parameters for these elements taken from the results of the finite-element analyses of car crush behavior.

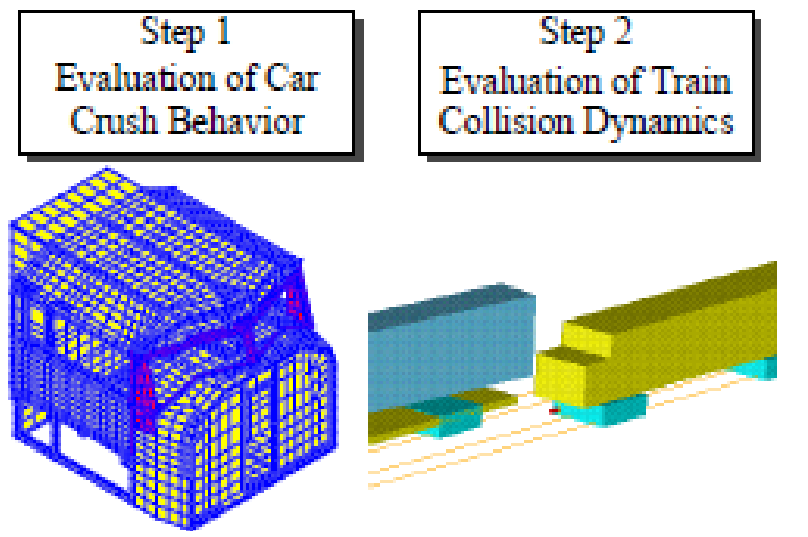

Fig. 3. SIMPLIFIED ANALYSIS APPROACH [17].

For Scenarios 2 and 3, manual calculations of structural strength were performed. Such calculations are similar to the first step illustrated in Figure 3. Highly-detailed computer simulations of all five scenarios are also being developed and exercised. The simplified analyses provide a relatively modest amount of information, while the detailed simulations provide voluminous information. It is expected that the results of the detailed simulation will be consistent with the results of the simplified analyses. A companion paper describes the results detailed computer simulations of tender performance [18].

\section{HYPOTHETICAL TENDER DESIGN}

A modified DOT 113 tank car design was selected as the basis for the hypothetical LNG tender design. DOT 113 cars are double-hulled tank-within-tank designs. The inner tank looks much the same as the outer tank, but has a smaller diameter and shorter length. Variations from the DOT 113 tank car design include the addition of rooftop and side cabinets to protect the plumbing and fittings. Figure 4 is a sketch of the hypothetical tender.

This material is declared a work of the U.S. Government and is not subject to copyright protection in the United States. Approved for public release; distribution is unlimited. 


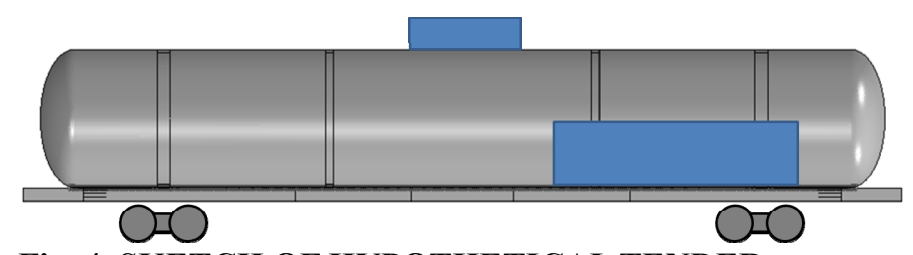

Fig. 4. SKETCH OF HYPOTHETICAL TENDER.

Table 2 lists parameters needed for simplified analysis and the values selected. The hypothetical LNG tender design has attributes selected from the range required by regulation [19]. The values chosen are arbitrary. Many of the parameters listed in Table 2 are constrained by current regulations for tank cars. For example, the inner tank material must be either ASTM A240 Type 304 or ASTM A240 304L. These materials are more ductile and have increased yield strength at cryogenic temperatures, over their properties at ambient temperatures. The outer tank material must be either AAR TC128 grade B or ASTM A-516-70 [20]. The outer tank head thickness must be at least 0.5 inches.

Table 2. HYPOTHETICAL TENDER DESIGN ATTRIBUTES

\begin{tabular}{|l|l|}
\hline \multicolumn{1}{|c|}{ Parameter } & \multicolumn{1}{c|}{ Value } \\
\hline Inner tank material & ASTM A240 Type 304L \\
\hline Inner tank thickness & 0.6 inch \\
\hline Outer tank material & AAR TC128, grade B \\
\hline Outer tank thickness & 0.5 inch \\
\hline Shell standoff & 6 inches \\
\hline Head standoff & 24 inches \\
\hline Inner tank pressure & 150 psi \\
\hline Outage & $10 \%$ \\
\hline Buff strength & 1,000 kips \\
\hline Weight & 260 kips \\
\hline
\end{tabular}

\section{SCENARIO 1: TRAIN-TO-TRAIN COLLISION}

Figure 5 shows a schematic of scenario 1, the train-to-train collision. In this scenario, a consist of three diesel locomotives collide with an LNG locomotive-fuel tender-LNG locomotive consist. The collision occurs on level tangent track.

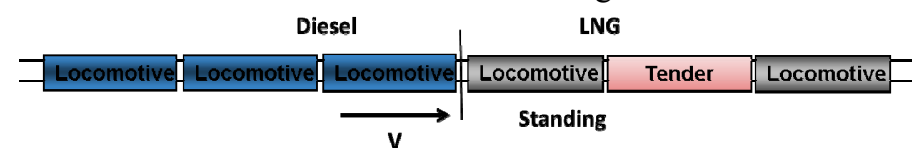

Fig. 5. SCHEMATIC OF SCENARIO 1 TRAIN-TOTRAIN COLLISION.

This scenario is derived from an accident that occurred in Two Harbors, Minnesota on September 30, 2010 [21]. In this accident, two trains collided at a closing speed of $42 \mathrm{mph}$. Both trains were led by three locomotives. The locomotives all remained essentially in-line, override did not occur, and all of the crew members survived.

This scenario was analyzed with a single-dimensional train model, with constant masses and force-crush characteristics acting in-between the masses. Three cases have been analyzed: all locomotives, as in the accident, with the hypothetical tender, and with a modified hypothetical tender. The force-crush characteristics for the locomotives were taken from analyses used to help develop AAR S-580 [4]. The force-crush characteristics for the hypothetical and modified hypothetical tender were estimated. A key assumption underlying this onedimensional model is the assumption of vertical and lateral motions of the equipment as the equipment interacts.

Figure 6 shows the expected interaction of the colliding locomotives. In the first step, the closed knuckles of the couplers just touch. As the locomotives move closer together in the second step, the couplers bottom out and the coupler horns are pressed into the strikers. The load through the strikers and into the locomotive increases until the draft gear boxes cripple and shear off, in the third step. The load then passes through the anti-climbers, until they cripple and are crushed solid, in the fourth step. The load passes through the crushed anti-climbers and increases until the locomotive underframe cripples. This mode and progression of damage is consistent with the observed damage to the colliding locomotives involved in the Two Harbors accident [21].

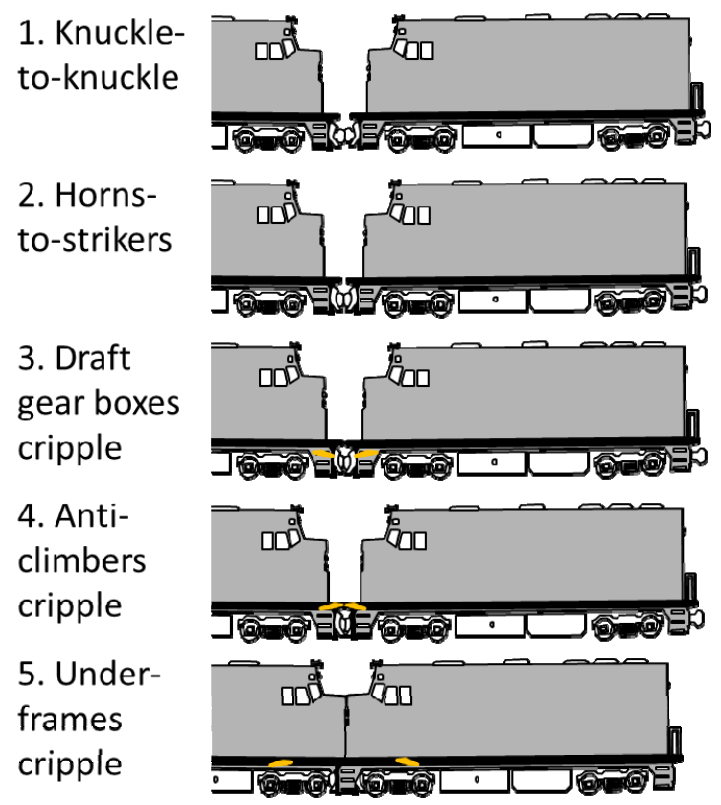

\section{Fig. 6. SCHEMATICS OF EXPECTED INTERACTION} OF COLLIDING LOCOMOTIVES

Figure 7 shows the expected interaction of the coupled traditional tender and locomotive. In the first step, the equipment is coupled and the draft gears are in neither buff nor draft. In the second step, the draft gears are compressed and the coupler horns are pressed into the strikers. In the third step, the load is passed through the strikers and increases until the locomotive draft gear box cripples and is sheared off; the tender underframe remains structurally intact. In the fourth step, the outer tank of the tender contacts the underframe of the locomotive. This mode and progression of damage requires that the tender underframe be stronger than the attachment of the draft gear box to the locomotive. Since the hypothetical tender is a hypothetical design, a strong underframe has been selected as an attribute.

This material is declared a work of the U.S. Government and is not subject to copyright protection in the United States. Approved for public release; distribution is unlimited. 


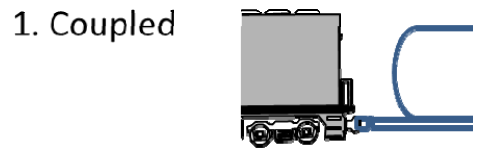

2. Horns-

to-strikers

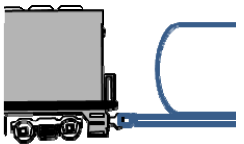

3. Locomotive draft gear box cripples

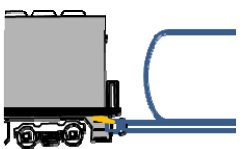

4. Tank

contacts

locomotive

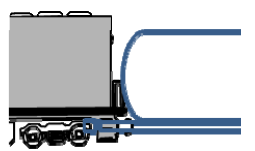

Fig. 7. SCHEMATICS OF EXPECTED INTERACTION OF COUPLED LOCOMOTIVE AND HYPOTHTICAL TENDER

Figure 8 shows a schematic of a modified tender. Modern crashworthiness techniques have been applied, and anticlimbers and support structures have been added to the tender. Properly implemented, such an anti-climber would manage the load path between the locomotive and tender underframes. Since the modified tender is also a hypothetical design, the crippling strength of the underframe has been selected to be $70 \%$ of a six-axle locomotive. The combination of the anticlimber, support structure, and underframe crippling strength are intended to increase protection of the tank by transferring the load effectively between the tender and locomotive.

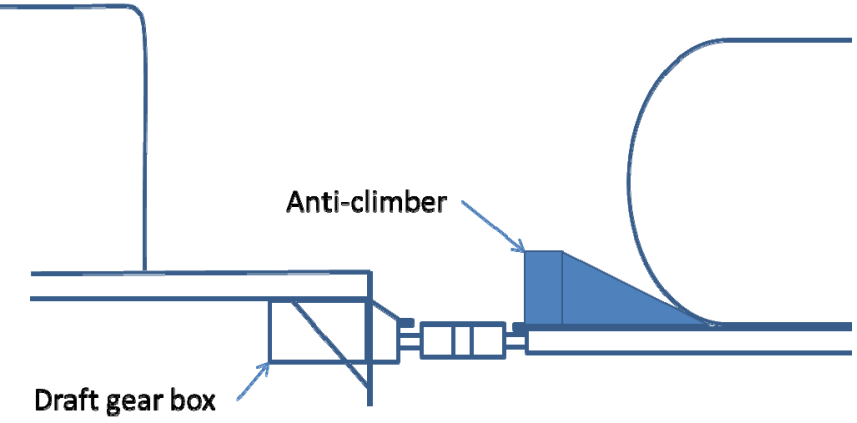

Fig. 8. SCHEMATIC OF HYPOTHETICAL TENDER MODERNIZATION

Figure 9 shows the expected interaction of the locomotive and the improved tender. In the first step, the equipment is coupled and the draft gears are in neither buff nor draft. In the second step, the draft gears are compressed and the coupler horns are pressed into the strikers. The load through the strikers increases until the locomotive draft gear box cripples and shears off, in the third step. In the fourth step, the tender anti-climber is loaded and eventually crushes solid. The load passes through the crushed anti-climber and increases until the tender underframe cripples.
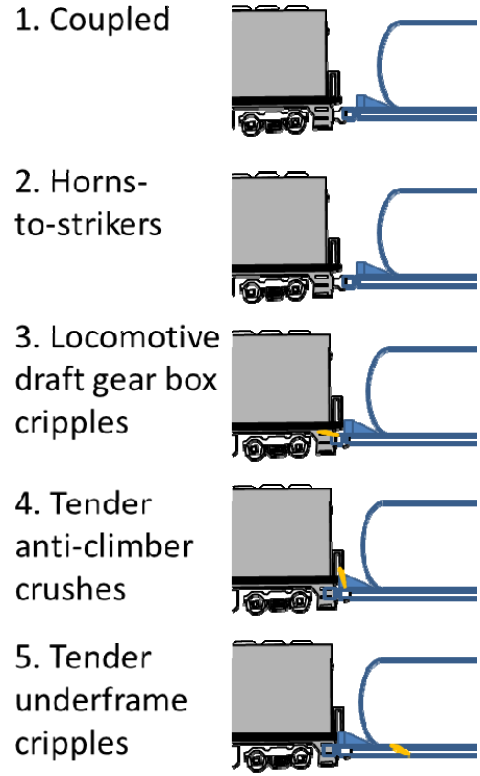

Fig. 9. SCHEMATICS OF EXPECTED INTERACTION OF COUPLED LOCOMOTIVE AND MODIFIED TENDER

Figure 10 is a graph of the three force/crush characteristics associated with the interaction steps depicted in Figures 6, 7, and 9. Crush on this plot is the difference in distance between points on the initial CGs of the interacting equipment. The red line is for the colliding locomotive interaction depicted in Figure 6. This line is annotated with numbers, which correspond to the steps shown in Figure 6. In the initial portion of the red line, from step 1 to step 2, the draft gear is loaded. The draft gear eventually bottom out, and the draft gear boxes are then loaded. The draft gear boxes then cripple and shear off in step 3. Shortly afterwards, the anti-climbers engage. They then cripple and eventually crush solid, in step 4 . The locomotive underframes are then loaded, and eventually cripple at a load of 10 million lbs in step 5.

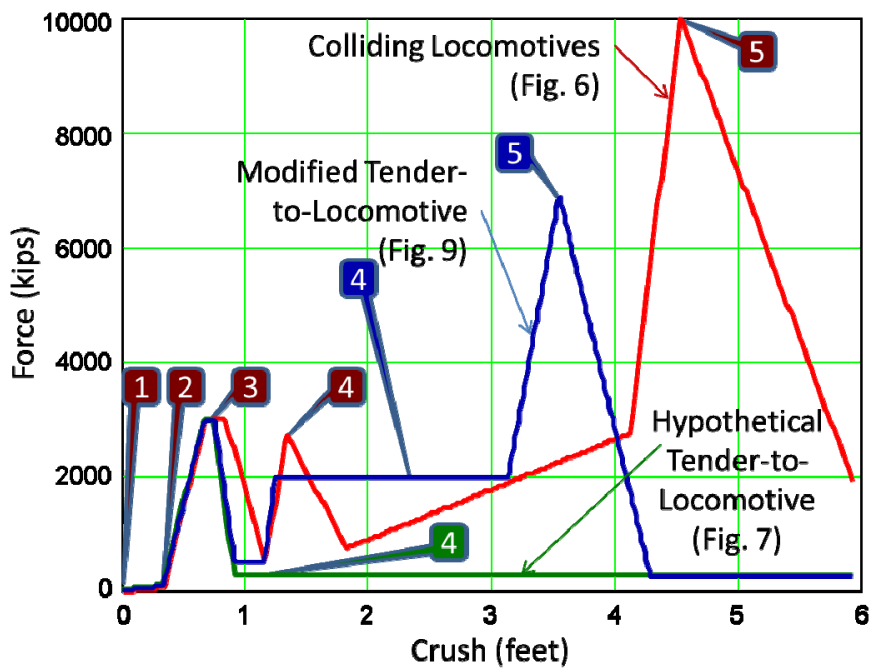

Fig. 10. FORCE-CRUSH CHARACETRISTICS ASSOCIATED WITH EXPECTED EQUIPMENT INTERACTIONS

This material is declared a work of the U.S. Government and is not subject to copyright protection in the United States. Approved for public release; distribution is unlimited. 
Similarly, the green line on the graph in Figure 10 is associated with the coupled locomotive-hypothetical tender interaction illustrated in Figure 7. The initial portion of the green line, steps 1 and 2 , are the same as for the colliding locomotive interaction. Step 3 is different for the locomotivehypothetical tender interaction, since there is only one locomotive draft gear box that is sheared off; the hypothetical tender underframe is expected to remain structurally intact. Once the locomotive draft gear box is sheared off, contact between the locomotive underframe and the outer tank of the tender then occurs, in green step 4.

And the blue line on the graph in Figure 10 is for the interaction of the locomotive and modified tender shown in Figure 9. The force crush line of the locomotive-modified tender is the same as the force crush curve of the locomotivehypothetical tender up to blue step 4 , when the modified tender anti-climber is engaged by the locomotive underframe. From that point on, the force is higher for the modified tender, as the load passes into the tender underframe. Eventually, the modified tender anti-climber is crushed solid, and the tender underframe is loaded. Since this is a hypothetical design, the crippling load has been made $70 \%$ of the crippling load of the locomotive, which is 7,000 kips.

Results from the single-dimensional train model include the longitudinal acceleration, velocity, and displacement timehistories. Figure 11 shows the velocity time histories for a 40 mph collision of a three diesel locomotive consist with an LNG locomotive-tender-locomotive consist. The colliding locomotives come to $20 \mathrm{mph}$ in just over 0.1 seconds. The middle north bound locomotive start to change speed as their leading draft gears bottom out. This is followed by their trailing draft gears bottoming out, and the middle equipment being shoved from behind.

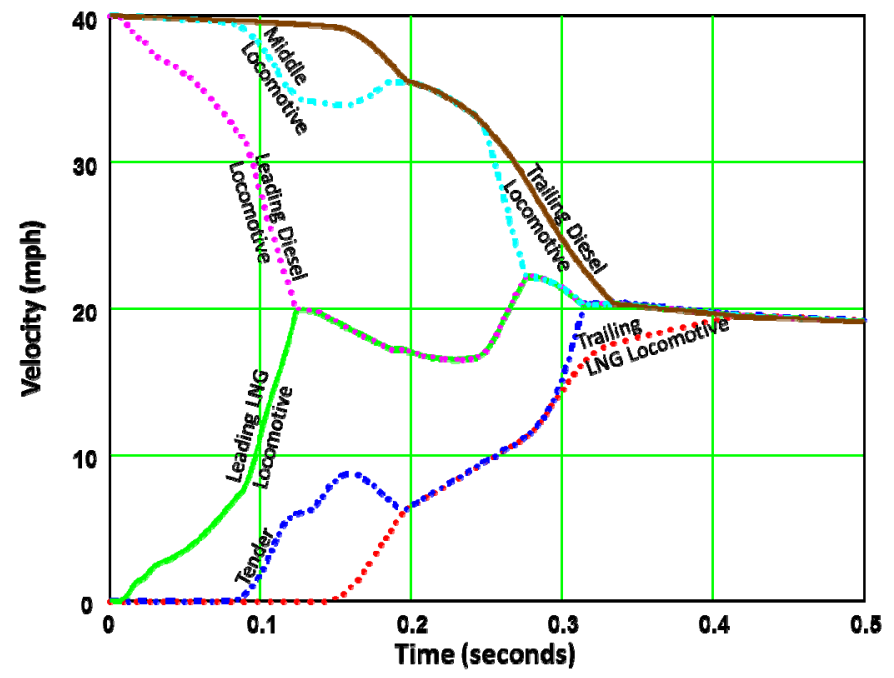

Fig. 11. VELOCTY TIME HISTORIES FOR COLLISION OF DIESEL CONSIST WITH LNG CONSIST.

The amount of crush between cars can be calculated from the displacement time-histories of the equipment. Figure 12 shows the crush time histories for the colliding locomotives, the leading LNG locomotive-and-tender, and the tender-andtrailing LNG locomotive.

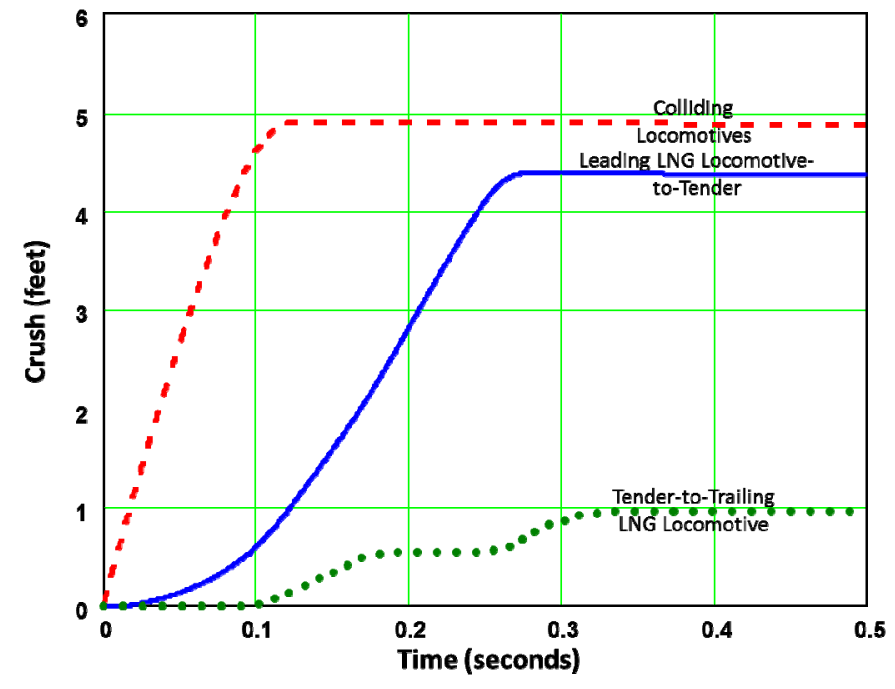

Fig. 12. CRSUH TIME HISTORIES FOR LNG EQUIPMENT IN COLLISION OF DIESEL CONSIST WITH LNG CONSIST.

Damage can be assessed by comparing the amounts of crush at 0.5 seconds with the force/crush curves in Figure 10 and the schematics shown in Figures 6 and 9. Figure 12 shows that the extent of crush for the colliding locomotives is just under 5 feet at 0.5 seconds. Figure 10 shows that 5 feet of crush is just beyond crippling for the colliding locomotive force crush curve, which is Step 5. Figure 6 shows the extent of damage to the locomotives expected for State 5. Similarly, Figure 12 shows that the extent of crush between the lead LNG locomotive and tender is about $4 \frac{1}{2}$ feet. Figure 10 shows that $4 \frac{1}{2}$ feet of crush is beyond crippling for the modified tender, at Step 5. Figure 9 shows the extent of expected damage to the locomotive and tender. There is less crush and damage at the tender-trailing LNG locomotive connection. One foot of crush is sufficient to cripple the locomotive draft gear box, but it is not sufficient to cripple the modified tender anti-climber.

This model has also been exercised at $25 \mathrm{mph}$ for a collision with the hypothetical tender and at $42 \mathrm{mph}$ for a collision of two consists of diesel locomotives, with both consists made up of three locomotives. In order to compare crashworthiness performance, the results were normalized to crush. This model is not able to directly calculate puncture of the LNG tank. The normalization is to an amount of crush where puncture of the tank appears imminent. For the hypothetical tender, tank puncture appears imminent after State 4 in Figure 7, with the tank directly contacting the locomotive. For the modified tender, tank puncture appears imminent after State 5, with crippling of the tender underframe. Figure 13 shows the normalized simulation results for the distribution of damage, for all three simulations.

The hypothetical tender consist was run at $25 \mathrm{mph}$, which was just sufficient to cause the tender tank head to contact the locomotive. And the modified tender consist was run at 40 mph, just sufficient to cripple the underframe of the modified tender and the colliding locomotive. The diesel locomotive consists were analyzed with a closing speed of $42 \mathrm{mph}$, as estimated for the Two Harbors accident. This speed is sufficient to cripple the lead and first trailing locomotives. The 
model was process validated by comparing simulation results for the extent of damage in the diesel locomotive case with photographs of the locomotives damaged in the Two Harbors accident. Details are not included in this paper.

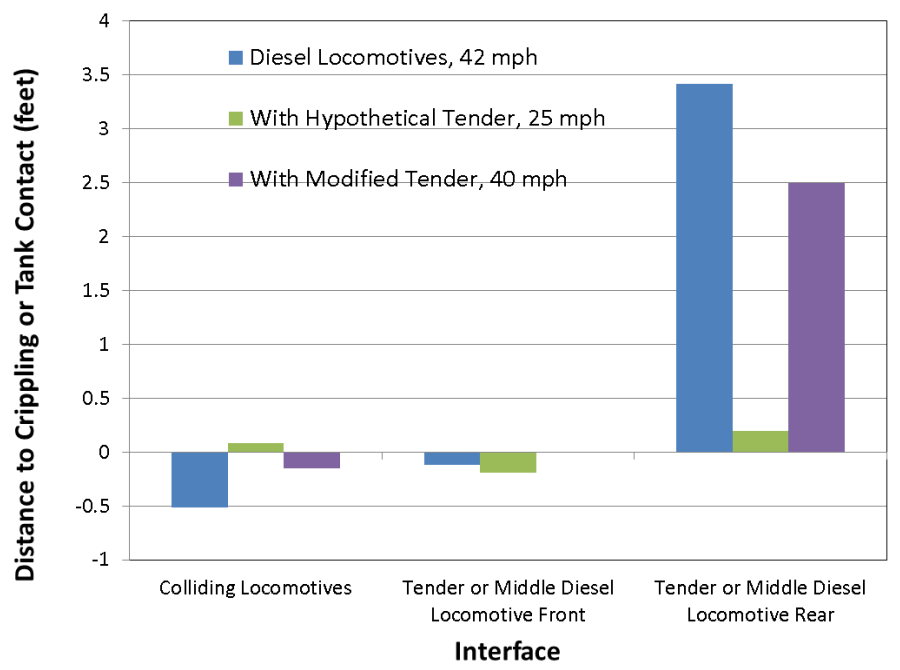

Fig. 13. BAR CHART OF EQUIPMENT DAMAGE FOR VARIOUS CONSISTS AND CLOSING SPEEDS

\section{SCENARIOS 2: GRADE-CROSSING IMPACT}

Figure 14 shows a schematic of the candidate gradecrossing impact scenario. In this scenario, a standing tender is impacted in the side by a highway tractor trailer. The track is level tangent track. This scenario was analyzed with classical closed-form structural analyses. Buckling and local yielding loads for plates that make up the structure were calculated. In essence, only Step 1 of the approach was used.
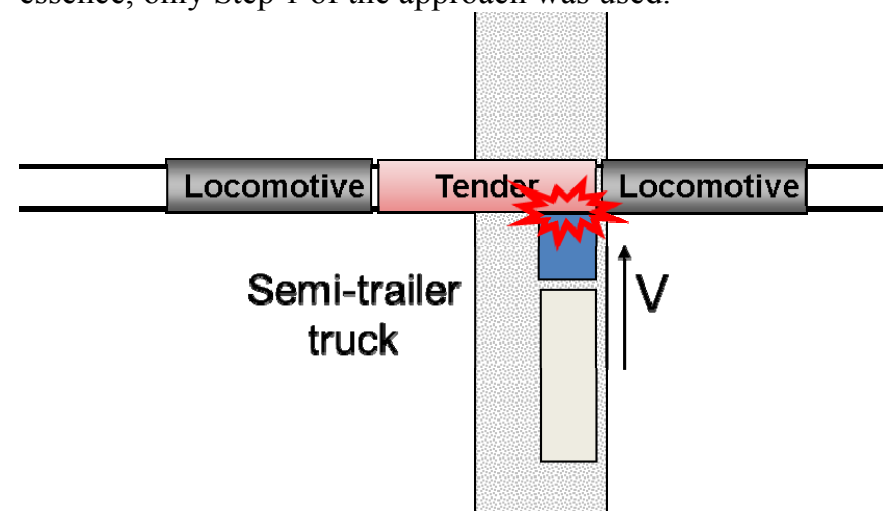

\section{Fig. 14. SCHEMATIC OF SCENARIO 2 GRADE- CROSSING COLLISION.}

Passenger equipment has a lateral static load requirement of $80 \mathrm{kips}$, which is intended to protect against a similar gradecrossing scenario [22]. This requirement is intended to allow the passenger equipment to derail rather than the structures lose integrity. In order to preserve this intent for the tender, the lateral load needs to be scaled to the weight of the tender. The lateral load for the tender is 210 kips. This load is greater than the 200 kip lateral load requirement in AAR S-5506 for diesel fuel tanks.

Figure 15 shows a schematic for the buckling load calculation for Scenario 2. The side plate is taken to be a simply supported square plate. In the most severe case, only one plate is loaded by the highway vehicle.

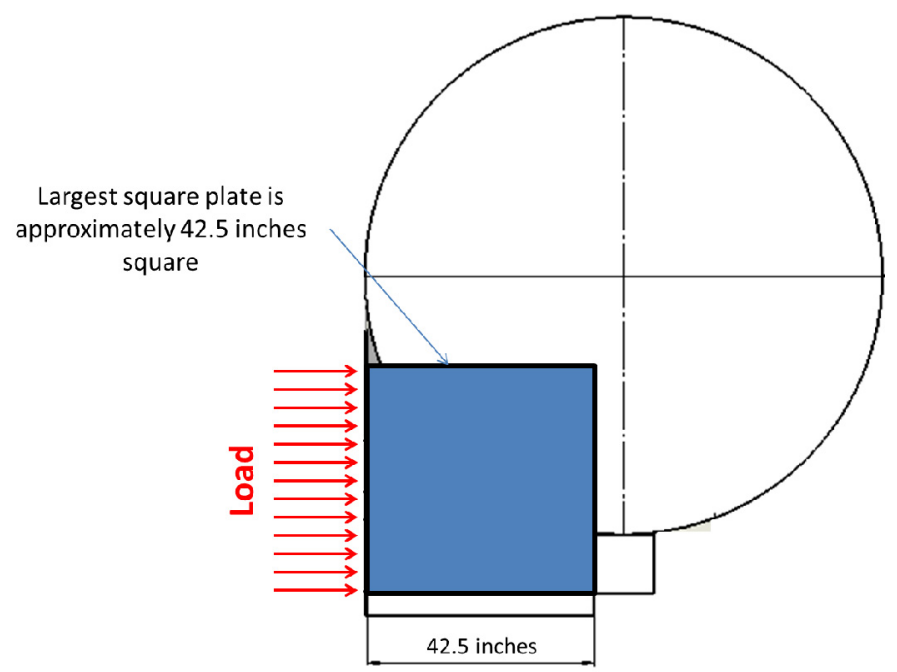

Fig. 15. SCHEMATIC OF BUCKLING LOAD. [23]:

The critical buckling stress is calculated with the equation

$$
\sigma:=\frac{\pi^{2} \cdot \mathrm{E}}{3 \cdot\left(1-v^{2}\right)} \cdot\left(\frac{t}{b}\right)^{2}
$$

For a material thickness of $7 / 16$ inch, and material properties for steel, the critical buckling stress is $11.5 \mathrm{ksi}$, and the associated load is 214 kips.

Since the buckling load is distributed all along one edge of the plate, local yielding of the cabinet sidewall was also calculated. For $7 / 16$ inch plate thickness, and $48 \mathrm{ksi}$ yield strength, the load would need to be concentrated over a length of 10 inches. For an ultimate strength of $80 \mathrm{ksi}$, the load would need to be concentrated over a length of 6 inches. For reference, typical passenger sill heights are in the range of 6 to 10 inches. The lateral load required by [22] would typically be applied over the height of the side sill. Local yielding is allowed by this regulation.

The results of the buckling and local yielding analyses indicate that the fundamental strength of a side cabinet with a side panel smaller than 42.5 inches square made of $7 / 16$ steel with at least $48 \mathrm{ksi}$ yield strength and $80 \mathrm{ksi}$ ultimate strength is sufficient to sustain the load associated with a low-to moderatespeed grade-crossing impact from a heavy highway vehicle.

\section{SCENARIO 3: ROLLOVER}

There are two candidates for the rollover scenario. Figure 16 shows a schematic of the first candidate. In this scenario, a tender is rolling with a tangential speed of $9 \mathrm{mph}$. The surface it rolls on is rigid and level. In this scenario, a concern is integrity of the roof structure that protect valves and fittings. This candidate is the same scenario as prescribed in [24].

This material is declared a work of the U.S. Government and is not subject to copyright protection in the United States. Approved for public release; distribution is unlimited. 


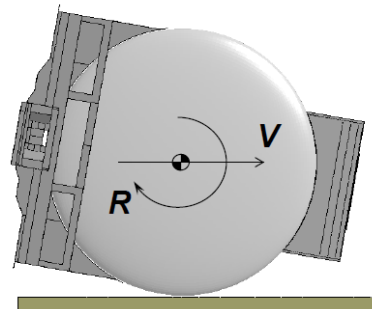

Fig. 16. SCHEMATIC OF FIRST CANDIDATE FOR SCENARIO 3 ROLLOVER [18].

Figure 17 shows the second candidate for the rollover scenario. In this scenario, a tender rotates about the outboard edge of the body bolsters, and the top fittings impact a rigid block of a prescribed shape. The point of rotation on the body is fixed, and does not translate. A concern is integrity of the roof structure that protects valves and fittings, the same as for the first candidate. The second candidate is the same as the conditions used to test an alternative hazmat tank car design [25].

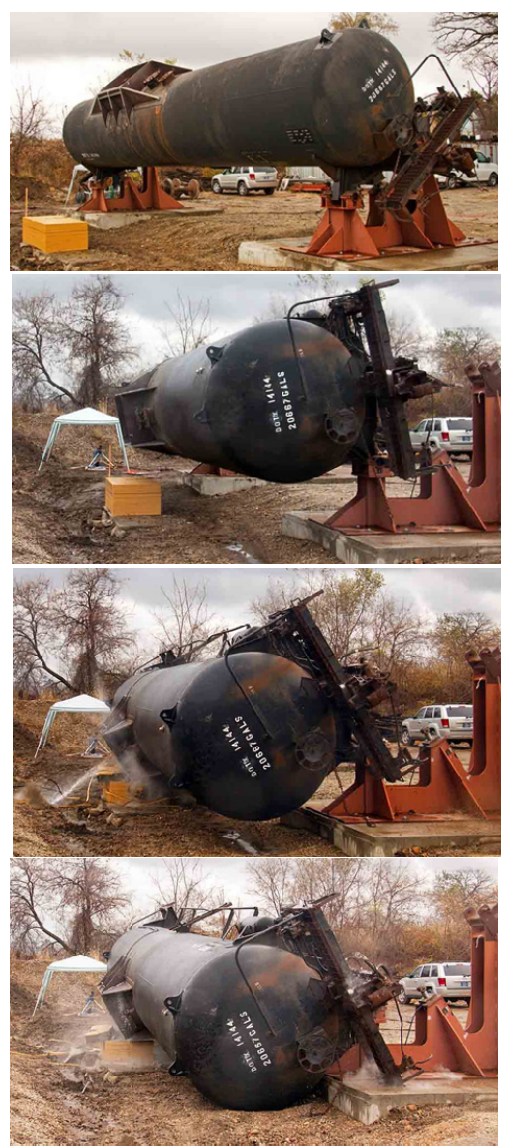

\section{Fig. 17. SCHEMATIC OF SECOND CANDIDATE FOR SCENARIO 3 ROLLOVER [26].}

There are tradeoffs between the two candidates for the rollover scenario. The first candidate is embodied in a federal regulation for hazmat tank cars that carry chlorine and ammonia. However, it appears to be difficult to set up a test that would allow the prescribed initial conditions. The prescribed conditions are mathematically feasible and can be analyzed with FEA. The second candidate can be tested, as has been demonstrated. The industry is not as familiar with the second candidate, since it is not currently embodied in a standard or regulation.

Similar closed-form structural analyses could be performed for the top structure of the hypothetical tender, as were performed for the side cabinets. The top structure and side cabinets were selected to be structurally similar. Details are not presented in this paper.

\section{SCENARIO 4: TANK SHELL IMPACTS}

Figure 18 shows the candidate shell impact scenario. In this scenario, a 290 kip ram car with an indenter impacts the center of the side of the tank. Tests of tank cars have been conducted using this configuration [27, 28]. The size of the indenter face for this scenario is 12 inches by 12 inches. The goal of the analysis of this scenario is the impact speed at which integrity of the inner tank is lost.

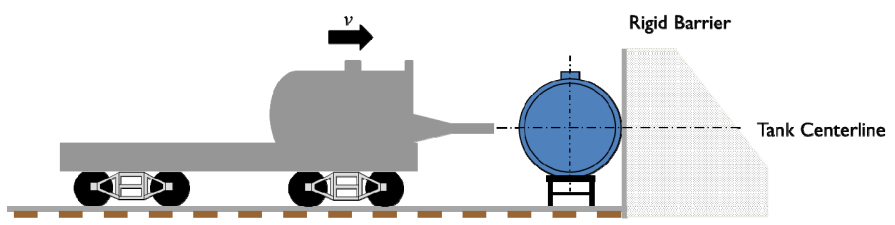

$$
\text { Moving Ram Car Stationary Tank Car }
$$

Fig. 18. SCHEMATIC OF SCENARIO 4 SHELL IMPACT.

Shell puncture was analyzed using the semi-empirical method described in detail in reference [29]. This method essentially extrapolates from the tests and detailed computer simulation performed of this impact condition. The method adjusts for material properties, material thickness, and the standoff distance between the inner and outer tank. For the hypothetical tender, it is estimated that the car-to-car velocity needed to cause rupture of the inner tank is between 24 and 30 mph. For comparison, the shell puncture velocity for jacketed DOT 105 tank cars, which carry liquefied chlorine and ammonia, has been estimated to be between 14 and $20 \mathrm{mph}$ [29].

Shell impacts similar to the impacts shown in Figure 18 can occur during derailments. Simulations of train derailments indicate that the most severe car-to-car impacts occur at roughly half the speed of the initial derailment [30]. So protecting against car-to-car impacts in the range of 24 to 30 $\mathrm{mph}$ is expected to provide protection in derailments that occur in the range of 48 to $60 \mathrm{mph}$.

\section{SCENARIO 5: TANK HEAD IMPACT}

Figure 19 shows a schematic of the head impact scenario. In this scenario, the center of the head of the tank is impacted by the indenter of a ram car. The face of the indenter is 12 inches by 12 inches. As for the shell impact scenario, the goal of the analysis of this scenario is integrity of the inner tank.

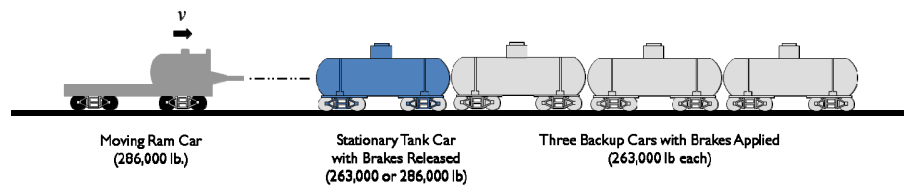

Fig. 19. SCHEMATIC OF SCENARIO 5 HEAD IMPACT.

Scenario 5 was analyzed in a similar fashion as Scenario 1, with a one-dimensional train collision dynamics model. Figure

This material is declared a work of the U.S. Government and is not subject to copyright protection in the United States. Approved for public release; distribution is unlimited. 
20 shows the expected mode of deformation of the tank head as it is deformed by the indenter. At Step 1, the indenter contacts the outer head, and there is no deformation. At Step 2, the outer head is deformed sufficiently to allow contact with the inner head. At Step 3, the inner tank ruptures.

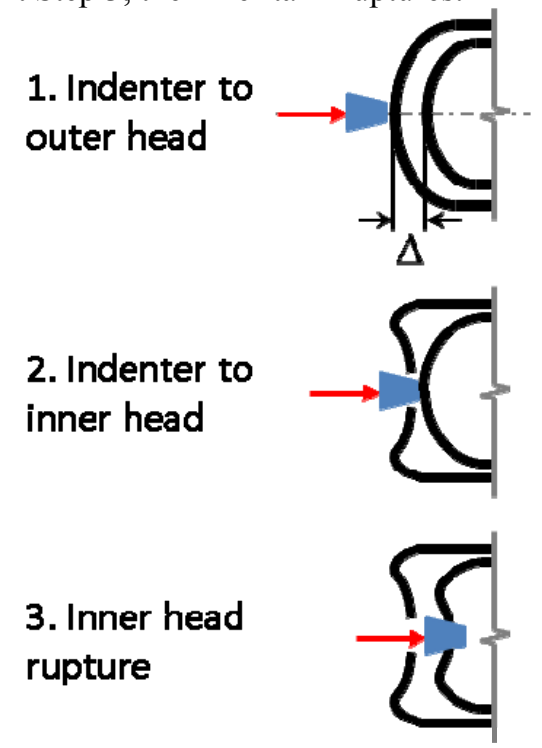

Fig. 20. EXPECTED MODE OF DEFORMATION FOR HEAD INDENTATION.

Figure 21 schematically illustrates the force/crush characteristic for the head, with the extent of crush associated with impact speed. At lower impact speeds, only the outer tank dents. At higher impact speeds, the outer and inner heads dent together and the slope of the force/crush characteristic increases. Tank rupture is estimated based on a simplified material failure model. Material failure is expected to occur when the shear stress exceeds the shear strength of the material.

Force

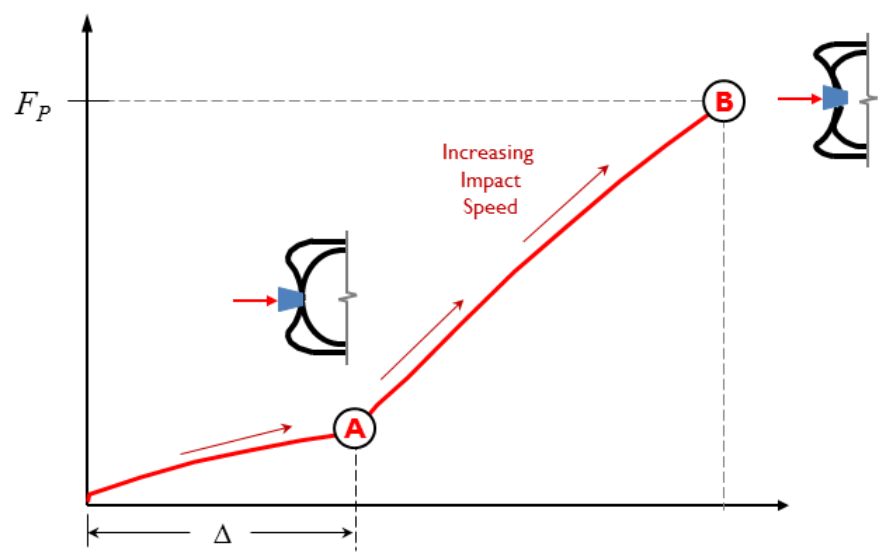

Indentation

Fig. 21. INPUT FORCE-INDENTATION CHARACTERISTIC FOR HEAD IMPACT ANALYSIS AND CALCULATED EXTENT OF CRUSH FOR 9, 25, AND 31 MPH IMPACTS.

For a $25 \mathrm{mph}$ head impact, the lower-bound estimate of the material shear strength is reached for the hypothetical tender. At $31 \mathrm{mph}$, the upper-bound estimate of the material shear strength is reached. For comparison, the head puncture velocity for jacketed DOT 105 tank cars, which carry liquefied chlorine and ammonia, has been estimated to be between 14 and $17 \mathrm{mph}$ [31]. Like shell impacts, head impacts can occur during derailments. As previously noted, simulations of train derailments indicate that the most severe car-to-car impacts occur at roughly half the speed of the initial derailment [30]. So protecting against head impacts in the range of 25 to $31 \mathrm{mph}$ is expected to provide protection in derailments that occur in the range of 50 to $62 \mathrm{mph}$.

\section{DISCUSSION}

Research is being conducted to support the development of effective natural gas fuel tender crashworthiness standards. This research is sponsored by FRA's Office of Research, Development, and Technology. This research is being conducted cooperatively with the AAR and research results are being shared with the AAR's NGFT TAG.

Five candidate scenarios have been proposed, which are intended to bound the range of accidents that such tenders might experience in widespread use on the general railroad system. These scenarios include a train-to-train collision, a grade-crossing collision, and three derailment related scenarios. The derailment scenarios are rollover, shell impact, and head impact.

Simplified analyses have been conducted on a hypothetical tender, to assess the crashworthiness performance in four of the five scenarios. No analyses were presented for the rollover scenario. In the train to train collision, the analysis results indicate that the hypothetical tender tank would contact the locomotive underframe in a $25 \mathrm{mph}$ collision. Analysis results for a modified tender with modern crashworthiness features indicate that the tender underframe would cripple in a $40 \mathrm{mph}$ collision. In the grade-crossing collision, analysis results indicate that plumbing cabinets made with $7 / 16$ inch thick sidewalls and steel with at least $48 \mathrm{ksi}$ yield strength could meet a lateral load associated with a low-to moderate-speed grade-crossing impact from a heavy highway vehicle. For the shell impact scenario, analysis results indicate that the hypothetical tender could sustain a derailment up to the range of 32 to $40 \mathrm{mph}$ while maintaining inner tank integrity. For the head impact scenario, analysis results indicate that the hypothetical tender could sustain a derailment up to the range of 50 to $62 \mathrm{mph}$ while maintaining inner tank integrity. These head and shell impact speeds are about $50 \%$ greater than can be sustained by tank cars designed to carry materials such as liquefied chlorine and liquefied ammonia.

The scenarios and analyses and results presented in this paper are part of the information needed to develop effective crashworthiness standards. The analysis techniques described in this paper all have some level of process validation. Analysis results for other designs have been compared with accident consequences or test measurements. And so there is some moderate level of confidence in the results. Confidence could be increased with model validation, anchoring the analysis results with tailored reality checks. Analysis results could be compared with material, component, and car tests particular to the analyzed design. The analyses techniques described in this paper can also be applied to help show 
compliance with crashworthiness standards, along with appropriate validation.

\section{ACKNOWLEDGMENTS}

This work was done as part of the Federal Railroad Administration's Equipment Safety Research Program. Melissa Shurland is the FRA's Program Manager and Kevin Kesler is the Chief, Equipment and Operating Practices Division, Office of Research and Development. The author thanks Dr. David Jeong, Senior Engineer, Volpe Center for performing the head and shell puncture analyses and providing the associated graphics. The author appreciates the efforts of Steve Clay, MP\&E Specialist, FRA Office of Safety for providing information on the Two Harbors accident. The author is grateful to Peter French, Assistant Vice President, Safety and Performance Analysis, AAR, for his accident review information and discussions on candidate scenarios. And finally, the author is thankful to Dr. Steven Kirkpatrick, Principal Engineer, ARA, for helping to smoothly coordinate industry and government research activities.

\section{REFERENCES}

[1].49 CFR Parts 229 and 238 Locomotive Crashworthiness; Final Rule. Federal Register, Vol. 71, No. 124, June 28, 2006.

[2].Code of Federal Regulations, Title 49, Appendix F to Part 238-Alternative Dynamic Performance Requirements for Front End Structures of Cab Cars and MU Locomotives. Federal Register, Vol. 75, No. 5, January 8, 2010.

[3].US Department of Transportation, Federal Railroad Administration, Docket No. FRA-2000-7257; Notice No. 71, Railroad Safety Advisory Committee (RSAC); Working Group Activity Update, Federal Register Vol. 77, No. 184, Friday, September 21, 2012.

[4].Association of American Railroads, AAR S-580 Standard, "Locomotive Crashworthiness Requirements," adopted December 2004, revised 2008.

[5].APTA SS-C\&S-016-99, Standard for Row-to-Row Seating in Commuter Rail Cars, The American Public Transportation Association, Washington, DC.

[6].The American Public Transportation Association, APTA RP-C\&S-XXX, Recommended Practice for Push-back Couplers in Passenger Rail Equipment, draft as of 7/1/08.

[7].Tyrell, D., Strang, J., Hynes, R., Peacock, T., Lydon, B., Woodbury, C.A., Stastney, J., "Development of a Crash Energy Management Specification for Passenger Rail Equipment" Compendium of Papers, 86th Annual Meeting, Transportation Research Board, Paper No. 07-0080 January 2007.

[8].http://articles.chicagotribune.com/2012-01-06/news/chifire-chemical-spill-after-trains-collide-in-nw-indiana20120106_1_second-train-crew-members-three-engines

[9].Llana, P., Stringfellow, R., Mayville, R., "Finite Element Analysis and Full-Scale Testing of Locomotive Crashworthy Components," American Society of Mechanical Engineers, Paper No. JRC2013-2546, April 2013.

[10].Carolan, M., Perlman, A.B., Tyrell, D., "Alternative Occupied Volume Integrity (OVI) Testing and Analyses,"
US Department of Transportation, DOT/FRA/ORD-13/46, October 2013.

[11].Association of American Railroads, AAR S-5506 Standard, "Performance Requirements for Diesel Electric Fuel Tanks," Adopted as a Recommended Practice: 1995; Upgraded to Standard: 2001.

[12].Jacobsen, K., "Fuel Tank Crashworthiness: Loading Scenarios," American Society of Mechanical Engineers, Paper No. JRC2011-56077, March 2011.

[13].Carolan, M., Sullivan, L., "Potential Scenarios of Concern for High Speed Rail Operations," American Society of Mechanical Engineers, Paper No. JRC2011-56074, March 2011.

[14].Jacobsen, K., Llana, P., Tyrell, D., "Collision Scenarios for Assessing Crashworthiness of Passenger Rail Equipment," American Society of Mechanical Engineers, Paper No. RTD2010-42033, October 2010.

[15].Llana, P., "Structural Crashworthiness Standards Comparison: Grade Crossing Collision Scenarios," American Society of Mechanical Engineers, Paper No. RTDF2009-18030, October 2009.

[16].Mayville, R.A.,Stringfellow, R.G., Rancatore, R.J., Hosmer, T.P., "Locomotive Crashworthiness Research, Volume 1: Model Development and Validation," DOT/FRA/ORD-95/08.1, 1995.

[17].Tyrell, D., Severson, K., Marquis, B., Martinez, E., Mayville, R., Rancatore, R., Stringfellow, R., Hammond, R., Perlman, A.B., "Locomotive Crashworthiness Design Modifications Study," Proceedings of the 1999 IEEE/ASME Joint Railroad Conference, Institute of Electrical and Electronics Engineers, Catalog Number 99CH36340, 1999.

[18].Kirkpatrick, S.W., Northrup, C., "Crashworthiness and Puncture Protection Analyses of LNG Tenders," American Society of Mechanical Engineers, Paper No. JRC20155812, March 2015.

[19].49 CFR Part 179-Specifications for Tank Cars, U.S. Government Publishing Office, October 1, 2011.

[20].AAR Manual of Standards and Recommended Practices, Section C-Part III, Specifications for Tank Cars, Specification M-1002, December 2000.

[21].National Transportation Safety Board, "Collision of Two Canadian National Railway Freight Trains near Two Harbors, Minnesota on September 30, 2010," NTSB/RAR-13/01/SUM, February 12, 2013.

[22].49 CFR § 238.417 Side loads, Federal Register / Vol. 64, No. 91, PP25685, May 12, 1999.

[23].Timoshenko, S., and Goodier, J.N., Theory of Elasticity, McGraw-Hill Book Company, 2nd Ed. 1951.

[24].49 CFR § 179.102-3 Material poisonous by inhalation, Federal Register / Vol. 74, No. 8, PP1770, January 13, 2009.

[25].Trent, R.S., Prabhakaran, A., González, F., Sharma, V. and Chitti, S., "Full Scale Tank Car Rollover TestSurvivability of Top Fittings and Top Fittings Protective Structure," American Society of Mechanical Engineers, Paper No. JRC2011-56105, March 2011.

[26].http://trn.trains.com/railroads/2009/12/rollover-tank-cartest

10

This material is declared a work of the U.S. Government and is not subject to copyright protection in the United States. Approved for public release; distribution is unlimited. 
[27].Tang, Y.H., Yu, H., Gordon, J.E., Priante, M., Jeong, D.Y., Tyrell, D.C., Perlman, A.B., "Analysis of Full-Scale Tank Car Shell Impact Tests," Proceedings of the 2007 ASME Rail Transportation Division Fall Technical Conference, RTDF2007-46010, September 2007.

[28]. Carolan, M.E. Jeong, D.Y., Perlman, A.B., Murty, Y.V., Namboordri, S., Kurtz, R., Elzey, R.K., Ananikitpaiboon, S., Tunna, L., Fries, R., "Application of Welded Steel Sandwich Panels for Tank Car Shell Impact Protection," Final Report DOT/FRA/ORD-13/19, April 2013.

[29].Jeong, D.Y., Tang, Y.H., Perlman, A.B., "Semi-Analytical Approach to Estimate Railroad Tank Car Shell Puncture," Proceedings of the 2011 ASME Joint Rail Conference, JRC2011-56028, Pueblo, Colorado, March 2011.

[30].Paetsch, C.R., Perlman, A.B., and Jeong, D.Y., "Dynamic Simulation of Train Derailments," Proceedings of 2006 ASME International Mechanical Engineering Congress and Exposition, November 5-10, 2006.

[31].Tang, Y.H., Yu, H., Gordon, Jeong, D.Y., Finite Element Analysis of Railroad Tank Car Head Impacts, RTDF200874022, Proceedings of the 2008 ASME Rail Transportation Division Fall Technical Conference, September 24-25, 2008. public release; distribution is unlimited. 